\title{
ANALISIS TINGKAT KESEHATAN PERUSAHAAN MENGGUNAKAN METODE EARNING DAN LEVERAGE PADA PERUSAHAAN
}

\author{
Fikri Ahmad Fauzi ${ }^{1}$, R. Deni Muhammad Danial ${ }^{2}$, Dicky Jhoansyah ${ }^{3}$ \\ Universitas Muhammadiyah Sukabumi ${ }^{1,2,3}$ \\ fikriacengg@gmail.com ${ }^{1}$
}

\begin{abstract}
ABSTRAK
Penelitian ini bertujuan untuk mengetahui metode earning (profitabilitas) dan leverage (solvabilitas) dalam mengukur tingkat kesehatan perusahaan pada PT. Adhi Karya (persero) Tbk dan PT. Surya Semesta Internusa Tbk. Penelitian ini menggunakan teknik analisis deskritif kuantitatf. Hasil dari penelitian ini menunjukan telah diketahui ada satu perusahaan yang dalam kondisi sehat dan satu perusahaan dalam kondisi kurang sehat. Simpulan, perusahaan yang dalam kondisi sehat dapat lebih mempertahankan sistemsistem kegiatan perusahaan yang sudah ada, dan bagi perusahaan yang kurang sehat, perusahaan harus cepat menangani atau segera melakukan suatu tindakan mengenai sistem kegiatan perusahan agar perusahaan tersebut bisa menjadi baik dan menjadi dalam kondisi perusahaan sehat.
\end{abstract}

Kata Kunci: Tingkat Kesehatan Perusahaan, Metode Earning dan Leverage

\section{ABSTRACT}

This study aims to determine the method of earnings (profitability) and leverage (solvency) in measuring the level of company health at PT. Adhi Karya (Persero) Tbk and PT. Surya Semesta Internusa Tbk. This research uses quantitative descriptive analysis techniques. The results of this study indicate that it is known that there is one company that is in a healthy condition and one company in an unhealthy condition. Conclusion, companies that are in a healthy condition can better maintain the company's existing system of activities, and for companies that are not healthy, the company must quickly handle or immediately take an action regarding the system of company activities so that the company can be good and be in company condition healthy.

Keywords: Company Soundness, Earning and Leverage Method

\section{PENDAHULUAN}

Di Indonesia ini perkembangan usaha semakin meningkat, terutama bagi perusahaan properti yang salah satunya merupakan perusahaan yang terlihat berkembang, dengan berjalannya waktu perkembangan pergantian ekonomi, banyaknya perusahaan properti yang hadir di Indonesia. Dan telah terjadinya persaingan antar perusahaan properti untuk menonjolkan kualitas dari pelayanan jasa yang begitu 
optimal.Maka dari itu perkembangan perusahaan salah satunya ditetapkan oleh kondisi laporan keuangan perusahaan tersebut.

Maka dari itu tingkat kesehatan perusahaan sangatlah dibutuhkan untuk meninjau suatu keuangan yang ada didalam perusahaan. Tingkat kesehatan merupakan keberhasilan perusahaan dalam melaksanakan aktivitas atau perencanaan suatu perusahaan. Perusahaan yang sehat tandanya adalah laporan keuangannya yang begitu baik dan pastinya akan menghasilkan sebuah keuntungan yang optimal. Dan hal ini dapat dilaksanakan dengan pengukuran dua perusahaan yang ada untuk mengetahui tingkat kesehatan perusahaan melalui earning (profitabilitas) dan leverage (solvabilitas) dalam mengukur dalam satu periode. Dan dapat dijelaskan dua rasio tersebut yaitu, earning (profitabilitas) merupakan proses mendapatkan keuntungan dengan lewat hasil penjualan dan total aset. Dan leverage (solvabilitas) merupakan sebuah ukuran untuk melihat total aset perusahaan, sudah sejauh mana pembiyayaan perusahaan dengan total utang.

Untuk meninjau laporan keuangan perusahaan PT. Adhi Karya (persero) Tbk dan PT. Surya Semesta Internusa Tbk ada beberapa aspek penilaian dilihat dari segi tingkat kesehatan perusahaan. Tingkat kesehatan perusahaan wajib melaksanakan kegiatan menilai tingkat kesehatan suatu perusahaan secara pribadi dengan menggunakan pendekatan earning (profitabilitas) dan leverage (solvabilitas). Tujuan salah satu penulis adalah untuk melihat kondisi suatu perusahaan yang sebenarnya apakah perusahaan tersebut dalam kondisi sehat atau tidak. Dan jika kondisi perusahaan mengalami kurang sehat, maka perlu mengambil sebuah tindakan. Dari tindak lanjut penilaian tingkat kesehatan perusahaan ini pada akhirnya akan menemukan kondisi laporan keuangan suatu perusahaan.

Untuk penelitian ini, yang akan diteliti oleh penulis kedepannya adalah didasari faktor kuantatifnya yaitu melalui earning dan leverage. Untuk perusahaan properti yang sudah terdaftar di Bursa Efek Indonesia periode 2013 sampai tahun 2017 dan di dalamnya menggunakan metode earning (profitabilitas) dan leverage (solvabilitas). Dengan uraian diatas penulis memilih dua perusahaan property dikarenakan ada permasalahan mengenai tingkat kesehatan. Maka dari itu laba bersih dari dari dua perusahaan diantara dua perusahaan tersebut mengalami penurunan pada tahun tertentu dan liabilitas dari dua perusahaan mengalami kenaikan pada tahun tertentu. 
Perusahaan PT. Adhi karya (persero) Tbk mengalami fluktuasi laba bersih dari tahun 2013 sampai tahun 2017 dan pada perusahaan PT.Surya Semesta Internusa Tbk mengalami penurunan sangat tajam dari tahun 2013 sampai tahun 2016 kemudian mengalami kenaikan dari tahun 2016 ke tahun 2017. Maka dari itu permasalahan laba bersih yang dialami oleh PT. Adhi Karya (persero) Tbk dan PT.Surya Semesta Internusa Tbk itu akan berdampak buruk pada tingkat kesehatan perusahaan tersebut.

Berdasarkan gambar nilai liabilitas diatas dapat diketahui jika nilai liabilitas suatu perusahaan mengalami kenaikan maka menandai tidak baik. Sebaliknya jika nilai liabilitas suatu perusahaan mengalami penurunan maka menandai baik. Nilai liabilitas pada perusahaan PT. Adhi karya (persero) Tbk mengalami kenaikan sangat pesat pada tahun 2013 sampai 2017. Dan pada perusahaan PT.Surya Semesta Internusa Tbk mengalami penurnan pada tahun 2013 ke 2014, kemudian mengalami kenaikan dari tahun 2014 sampai 2017.

Maka dari itu permasalahan mengenai meningkatnya nilai liabilitas dari dua perusahaan tersebut akan menimbulkan dampak negatif pada tingkat kesehatan perusahaan.

\section{KAJIAN TEORI}

\section{Kesehatan Perusahaan}

Kesehatan perusahaan merupakan hal terpenting yang mendorong terjaganya eksitensi sebuah perusahaan atau juga bisa disebut kesehatan perusahaan merupakan suatu hal yang penting untuk memberikan masukan supaya keberadaan perusahaan tetap terjaga.

\section{Pengertian Laporan Keuangan}

Hery (2012) menyatakan bahwa "laporan Keuangan adalah hasil dari proses akuntansi yang dapat digunakan sebagai alat untuk mengkomunikasikan data keuangan atau aktivitas perusahaan kepada pihak-pihak yang berkepentingan". Oleh karena itu berdasarkan pengertian menurut teori maka dapat disimpulkan uraian diatas bahwa laporan keuangan yaitu sarana pengetahuan tentang informasi yang mencakup tentang kegiatan keuangan perusahaan. 
Bambang Wahyudiono (2014) menyatakan bahwa "laporan keuangan merupakan alat komunikasi utama perusahaan, perusahaan dapat mengomunikasikan kegiatan proses produksi atau bisnisnya, perusahaan bisa berupaya mencari investor baru bahkan pengajuan kredit ke bank untuk mendapatkakan pembiayaan baru, instansi pajak dapat menerima alasan perusahaan rugi sehingga belum bisa bayar pajak alias nihil dan manajer SDM dapat menyakinkan kepada buruh dan karyawan kalau pada suatau periode perusahaan belum mampu member kenaikan gaji”.

Munawir (2013) menyatakan bahwa "laporan keuangan pada dasaarnya adalah hasil dari proses akuntansi yang dapat digunakan sebagai alat untuk berkomunikasi antara data keuangan atau aktivitas suatu perusahaan dengan pihak-pihak yang berkepentingan dengan data atau aktivitas perusahaan tersebut”.

\section{Metode Earning (Profitabilitas) dan Leverage (Solvabilitas)}

Hery (2015) menyatakan bahwa "Earning (profitibilitas) merupakan rasio yang yang digunakan untuk mengukur kemampuan perusahaan dalam menghasilkan laba dari aktivitas normal bisnisnya". Dan dapat disimpulkan definisi mengenai earning (profitabilitas), bahwa earning merupakan cara pengukuran suatu perusahaan untuk melihat laba yang akan dihasilkannya melewati aspek-aspek hasil upayah perusahaan dalam menjual produknya tersebut.

Untuk mengukur tingkat kesehatan suatu perusahaan penulis menggambil beberapa cara untuk mengukurnya dengan menggunakan Earning (profitabilitas) ada lima indikatornya yaitu: 1) return on Asset, 2) return on Equitty, 3) Gross Profit MARGIN, 4) Operating Profit Margin, 5) Net Profit Margin

Danang Sunyoto (2013) menyatakan bahwa "Leverage (Solvabilitas) adalah kemampuan untuk memenuhi seluruh kewajiban perusahaan yang meliputi utang jangka pendek dan utang jangka panjang, baik perusahaan masih berjalan maupun dalam keadaan dilikuiditas (dibubarkan)”.

Dapat disimpulkan uraian diatas bahwa Leverage (Solvabilitas) merupakan pemberi petunjuk bagi perusahaan yang dapat memperoses hutang-hutangnya untuk mencapai keuntungan.

Adapaun indikator-indikator dari Leverage (solvabilitas) untuk mengukur tingkat kesehatan perusahaan penulis mengambil beberapa cara untuk mengukurnya 
yaitu: 1) debt to Asset Ratio, 2) debt to Equity Ratio, 3) long Term Debt to Equity Ratio, 4) Times Interesr Earned Ratio, 5) Operating Income to Liabilities Ratio

Tingkat kesehatan pada perusahaan untuk melihat kondisi suatu perusahaan apakah sedang kondisi lagi sehat atau tidak sehat, tingkat kesehatan perusahaan dapat diukur dengan dua faktor yaitu dengan menggunakan earning dan leverage dan telah dijelaskan di atas bahwa hasil tingkat kesehatan perusahaan akan diketahui setelah pengukurannya telah dilakukan selama setiap satu periode. Maka dari itu metode earning (profitabilitas) dan leverage (solvabilitas) untuk mengukur tingkat kesehatan pada perusahaan PT. Adhi Karya (persero) Tbk dan PT. Surya Semesta Internusa yang sudah terdaftar di Bursa Efek Indonesia

\section{METODE PENELITIAN}

Metode penelitian yang dipergunakan peneliti untuk mendapatkan atau memperoleh hasil jawaban dari masalah yang akan diteliti oleh peneliti ialah metode penelitian deskritif kuantitatif. Oleh sebab itu metode penelitian deskritif yang berkaitan dengan kuantitatif dipergunakan untuk memaparkan atau menggambarkan suatu kejadian atau peristiwa yang berbentuk angka.

Penelitian ini menggunakan cara data sekunder yaitu mengambil informasi ataupun data yang berasal dari web.idx.id dan www.idx.com. Yaitu berupa laporan keuangan perusahaan PT. Adhi Karya (perero) Tbk dan PT. Surya Semesta Internusa Tbk dalam tahun 2013 sampai 2017. Yang telah dijadikan suatu analisis penelitian dengan menggunakan teknik-teknik yang sudah ada, ataupun dari sumber yang akan diteliti data-data yang bisa didapatkan melalui dari buku, informasi lainnya ataupun dari kepustakaan.

\section{HASIL PENELITIAN}

Tabel 1 Hasil Perhitungan PT. Adhi Karya (Persero) Tbk. Earning (Profitabilitas)

\begin{tabular}{cccccc}
\hline Tahun & $\mathbf{2 0 1 3}$ & $\mathbf{2 0 1 4}$ & $\mathbf{2 0 1 5}$ & $\mathbf{2 0 1 6}$ & $\mathbf{2 0 1 7}$ \\
\hline ROA & $4,20 \%$ & $3,12 \%$ & $2,77 \%$ & $1,57 \%$ & $1,82 \%$ \\
ROE & $263,7 \%$ & $18,64 \%$ & $9,00 \%$ & $5,78 \%$ & $8,80 \%$ \\
GPM & $12,17 \%$ & $11,53 \%$ & $10,38 \%$ & $10,07 \%$ & $13,57 \%$ \\
OPM & $83,90 \%$ & $8,53 \%$ & $6,50 \%$ & $6,58 \%$ & $11,26 \%$ \\
NPM & $4,16 \%$ & $3,77 \%$ & $4,95 \%$ & $2,84 \%$ & $3,41 \%$ \\
\hline
\end{tabular}


Berdasarkan hasil tabel diatas bahwa PT. Adhi Kaya (persero) Tbk untuk hasil perhiutangam earning (profitabilitas). Untuk hasil ROAnya dari tahun 2013 - 2017 mengalami fluktuasi, lalu hasil ROE nya mengalami penurunan daari tahun 2013 2016 dan namun, terjadi kenaikkan pada tahun 2017, kemudian hasil GPM dari tahun mengalami penurunan dari tahun 2013 - 2016 dan terjadi kenaikkan pada tahun 2017, hasil OPM mengalami penurunan pada tahun 2013 - 2015 namun, terjadi kenaikan lagi pada tahun 2016 - 2017 dan yang trakhir hasil NPM mengalami fluktuasi dari tahun $2013-2017$.

Tabel 2 Hasil Perhitungan PT. Surya SEMESTA Internusa Tbk. Earning (Profitabilitas)

\begin{tabular}{cccccc}
\hline Tahun & $\mathbf{2 0 1 3}$ & $\mathbf{2 0 1 4}$ & $\mathbf{2 0 1 5}$ & $\mathbf{2 0 1 6}$ & $\mathbf{2 0 1 7}$ \\
\hline ROA & $12,84 \%$ & $8,57 \%$ & $5,92 \%$ & $1,40 \%$ & $14,02 \%$ \\
ROE & $28,58 \%$ & $16,90 \%$ & $11,47 \%$ & $3,00 \%$ & $27,72 \%$ \\
GPM & $28,80 \%$ & $23,61 \%$ & $24,21 \%$ & $20,35 \%$ & $26,38 \%$ \\
OPM & $21,24 \%$ & $12,88 \%$ & $13,30 \%$ & $11,69 \%$ & $61,95 \%$ \\
NPM & $16,29 \%$ & $11,50 \%$ & $7,87 \%$ & $2,65 \%$ & $38,22 \%$ \\
\hline
\end{tabular}

PT.Surya Semesta Internusa Tbk untuk hasil perhitungan earning (profitabilitas).Untuk hasil ROA mengalami penurunan dari tahun 2013-2016 namun, pada tahun 2017 terjadi kenaikkan, lalu hasil ROE mengalami penurunan dari tahun 2013 - 2016 namun, terjadi kenaikkan pada tahun 2017, kemudian hasil GPM mengalami fluktuasi dari tahun 2013 - 2017, hasil OPM sama mengalami fluktuasi dari tahun 2013 - 2017 dan untuk hasil NPM mengalami penurunan dari tahun 2013 - 2016 namun, terjadi kenaikkan pada tahun 2017.

Tabel 3 Hasil Perhitungan Rata-Rata Industri Sektor Properti

\begin{tabular}{cccccc}
\hline Rata-rata & $\mathbf{2 0 1 3}$ & $\mathbf{2 0 1 4}$ & $\mathbf{2 0 1 5}$ & $\mathbf{2 0 1 6}$ & $\mathbf{2 0 1 7}$ \\
\hline ROA & $6,03 \%$ & $5,34 \%$ & $3,83 \%$ & $6,52 \%$ & $58,81 \%$ \\
ROE & $54,27 \%$ & $16,63 \%$ & $11,90 \%$ & $16,27 \%$ & $14,45 \%$ \\
GPM & $14,86 \%$ & $13,75 \%$ & $14,20 \%$ & 14,505 & $16,55 \%$ \\
OPM & $22,32 \%$ & $10,66 \%$ & $9,02 \%$ & $9,72 \%$ & $16,64 \%$ \\
NPM & $6,70 \%$ & $5,88 \%$ & $5,73 \%$ & 10,23 & $11,66 \%$ \\
\hline
\end{tabular}

Dan mengenai rata-rata industri sektor properti bagian konstruksi dan bangunan earning (profitabilitas) dapat dilihat dari nilai ROA mengalami peurunan dari tahu 2013 - 2015 namun, terjadi kenaikkan dari tahun 2016 - 2017, untuk nilai ROE mengalami fluktuasi dari tahun 2013 - 2017, nilai GPM mengalami fluktuasi dari tahun 2013 - 
2017, nilai OPM mengalami penurunan dari tahun 2013 - 2015 namun, terjadi kenaikkan dari tahun 2016 - 2017 dan untuk nilai NPM mengalami mengalami fluktuasi

Kemudian dibawah ini ada tabel perhitungan leverage (solvabilitas) pada perusahaan PT. Adhi Karya (persero) Tbk dan PT. Surya Semesta Internusa Tbk sebagai berikut:

Tabel 4 Hasil Perhitungan PT. Adhi Karya (Persero) Tbk. Leverage (Solvabilitas)

\begin{tabular}{cccccc}
\hline Tahun & $\mathbf{2 0 1 3}$ & $\mathbf{2 0 1 4}$ & $\mathbf{2 0 1 5}$ & $\mathbf{2 0 1 6}$ & $\mathbf{2 0 1 7}$ \\
\hline DAR & $84,07 \%$ & $83,25 \%$ & $69,20 \%$ & $72,83 \%$ & $79,28 \%$ \\
DER & $515,7 \%$ & $497,1 \%$ & $224,6 \%$ & $286,1 \%$ & $382,6 \%$ \\
LTDER & $105,3 \%$ & $93,49 \%$ & $42,31 \%$ & $29,54 \%$ & $82,27 \%$ \\
TIER & $686,9 \%$ & $402,5 \%$ & $542,7 \%$ & $237,4 \%$ & $215,2 \%$ \\
OILR & $10,06 \%$ & $8,47 \%$ & $5,26 \%$ & $4,99 \%$ & $7,60 \%$ \\
\hline
\end{tabular}

Berdasarkan hasil tabel diatas pada PT. Adhi Karya (persero) untuk hasil perhitungan leverage (solvabilitas). Untuk hasil DAR mengalami mengalami penurunan dari tahun 2013 - 2015 namun, dari tahun 2016 - 2017 mengalami kenaikkan, hasil DER mengalami penurunan dari tahun 2013 - 2015 namun, terjadi kenaikkan dari tahun 2016 - 2017, hasil LTDER mengalami penurunan dari tahun 2013 - 2016 namun, terjadi kenaikkan pada tahun 2017, hasil TIER mengalami fluktuasi dan hasil OILR mengalami penrunan dari tahun 2013 - 2016 namun, terjadi kenaikkan pada tahun 2017.

Tabel 5 Hasil Perhitungan PT. Surya Semesta Internusa Tbk. Leverage (solvabilitas)

\begin{tabular}{cccccc}
\hline Tahun & $\mathbf{2 0 1 3}$ & $\mathbf{2 0 1 4}$ & $\mathbf{2 0 1 5}$ & $\mathbf{2 0 1 6}$ & $\mathbf{2 0 1 7}$ \\
\hline DAR & $55,08 \%$ & $49,29 \%$ & $48,35 \%$ & $53,40 \%$ & $49,42 \%$ \\
DER & $122,6 \%$ & $97,21 \%$ & $93,64 \%$ & $114,6 \%$ & $97,71 \%$ \\
LTDER & $51,64 \%$ & $40,38 \%$ & $38,02 \%$ & $50,04 \%$ & $50,74 \%$ \\
TIER & $689,0 \%$ & $516,9 \%$ & $280,7 \%$ & $51,58 \%$ & $69,57 \%$ \\
OILR & $30,38 \%$ & $19,47 \%$ & $20,71 \%$ & $11,47 \%$ & $46,37 \%$ \\
\hline
\end{tabular}

Pada PT. Surya Semesta Internusa Tbk untuk hasil perhitungan leverage (solvabilitas). Untuk hasil DAR mengalami fluktuasi, hasil DER mengalami fluktuasi, hasil LTDER mengalami penurunan dari tahun 2013 - 2015 namun, terjadi kenaikkan pada tahun 2016 - 2017, hasil TIER mengalami mengalami penurunan dari tahun 2013 - 2016 namun, terjadi kenaikkan pada tahun 2017 dan hasil OILR mengalami penurunan dari tahun 2013 - 2016 namun, terjadi kenaikkan pada tahun 2017. 
Tabel 6 Hasil Perhitungan Rata-rata Industri Sektor Properti

\begin{tabular}{cccccc}
\hline Rata-rata & $\mathbf{2 0 1 3}$ & $\mathbf{2 0 1 4}$ & $\mathbf{2 0 1 5}$ & $\mathbf{2 0 1 6}$ & $\mathbf{2 0 1 7}$ \\
\hline DAR & $59,26 \%$ & $67,97 \%$ & $64,97 \%$ & $63,33 \%$ & $66,42 \%$ \\
DER & $284,6 \%$ & $275,2 \%$ & $197,8 \%$ & $188,4 \%$ & $225,3 \%$ \\
LTDER & $53,03 \%$ & $53,40 \%$ & $44,70 \%$ & $38,90 \%$ & $49,27 \%$ \\
TIER & $428,5 \%$ & $379,1 \%$ & $280,4 \%$ & $173,5 \%$ & $172,9 \%$ \\
OILR & $16,17 \%$ & $13,59 \%$ & $11,1 \%$ & $10,19 \%$ & $15,14 \%$ \\
\hline
\end{tabular}

Dan mengenai rata-rata industri sector properti bagian konstruksi dan bangunan leverage (solvabilitas). Untuk nilai DAR mengalami fluktuasi, nilai DER mengalami penurunan dari tahun 2013 - 2016 namun, terjadi kenaikkan pada tahun 2017, nilai LTDER mengalami mengalami fluktuasi, nilai TIER mengalami fluktuasi dan nilai OILR mengalami penurunan dari tahun 2013 - 2015 namun, terjadi kenaikkan dari tahun 2016 - 2017.

\section{PEMBAHASAN}

Metode analisis yang digunakan dalam penelitian ini ialah menggunakan analisi rasio keuangan, untuk mengetahui tingkat kesehatan perusahaan dapat dilihat dari tingkat earning( profitabilitas) dan leverage (solvabilitas) perusahaan tersebut. Dan dalam penelitian ini mempergunakan analisis laporan keuangan untuk melihat kondisi keuangan yang ada diperusahaan sehingga dapat diketahui perusahaan sedang mengalami turun atau naiknya earning (profitabilitas) dan leverage (solvabilitas) pada perusahaan tersebut.

Untuk menilai earning (profitabilitas) dan leverage (solvabilitas) yang ada diperusahaan tersebut dapat dilaksanakan dengan membandingkan rasio earning (profitabilitas) dan leverage (solvabilitas) PT. Adhi Karya (Persero) Tbk dan PT. Surya Semesta Internusa Tbk dengan perusahan yang sama atau sejenis. Maka dari itu perhitungan rata-rata standar industri perusahaan yang sama atau sejenis dengan PT. Adhi Karya (Persero) Tbk dan PT. Surya Semesta Internusa Tbk. Ialah perusahaan yang termasuk dalam perusahaan sub sector properti bagian konstruksi dan bangunan yang sudah terdaftar di Bursa Efek Indonesia.

Earning (profitabilitas) merupakan rasio yang mempunyai suatu misi pencapaian perusahaan untuk melihat kondisi perusahaan dalam menghasilkan keuntungan 
perusaahaan selama satu tahun dan untuk juga mengukur mengenai efektivitas manajemen perusahaan dalam melaksanakan kegiatannya.

Leverage (solvabilitas) adalah rasio yang memperlihatkan kesangupan perusahaan dalam melunasi segala utang atau kewajiban perusahaan baik jangka pendek maupun jangka panjang. Dan dibawah ini ada tabel mengenai perhitungan earning (profitabilitas).

\section{SIMPULAN}

Berdasarkan hasil analisis dan pembahasan dalam penelitian ini dapat memberikan hasil kesimpulan sebagai berikut:

1. PT. Adhi Karya (persero) Tbk. Memiliki nilai return on asset yang kurang sehat yang disebabkan masih dibawah nilai rata-rata industri. Untuk return on equity dari tahun 2013-2014 mendapatkan hasil yang baik dalam kondisi sehat disebabkan masih diatas nilai rata-rata industri, namun pada tahun 2015-2017 hasilnya kurang sehat disebabkan masih dibawah nilai rata-rata industri. Lalu untuk gross profit margin dalam kondisi kurang sehat disebabkan masih dibawah nilai rata-rata industri. Kemudian untuk operating profit margin pada tahun 2013 mendapatan hasil yang baik dalam kondisi sehat disebabkan masih diatas nilai rata-rata industri namun, dari tahun 2014-2017 hasilnya kurang sehat masih dibawah nilai rata-rata industri dan untuk net profit margin dalam kondisi kurang sehat disebabkan masih dibawah nilai rata-rata industri. PT. Surya Semesta Internusa Tbk memiliki return on asset dari tahun 2013-2015 mendapatkan hasil yang baik dalam kondisi sehat disebabkan masih diatas nilai rata-rata industri namun dari tahun 2016-2017 hasilnya kurang sehat disebabkan masih dibawah nilai rata-rta indsutri. Untuk return on equity 2013, 2015-2016 hasilnya kurang sehat disebabkan masih dibawah nilai ratarata industri namun pada tahun 2014 dan 2017 mendapatkan hasil yang baik dalam kondisi sehat disebabkan masih diatas nilai rata-rata industri. Lalu gross profit margin mendapatkan hasil yang baik dalam kondisi sehat disebabkan masih diatas nilai rata-rata industri. Kemudian operating profit margin pada tahun 2013 hasilnya kurang sehat disebabkan masih dibawah nilai rata-rata industri namun, dari tahun 2014-2017 mendapatkan hasil yang baik dalam kondisi sehat disebabkan masih diatas nilai rata-rata industri dan untuk net profit margin mendapatkan hasil yang 
baik dalam kondisi sehat dari tahun 2013-2015 dan 2017 disebabkan masih diatas nilai rata-rata industri namun, pada tahun 2016 hasilnya kurang sehat disebabkan masih dibawah nilai rata-rata industri. Oleh karena itu pada perusahaan PT. Surya Semesta Internusa Tbk lebih unggul dan lebih sehat dalam kemampuan untuk mendapatkan laba atau keuntungan dibandingkan pada perusahaan PT. Adhi Karya (persero) Tbk.

2. PT. Adhi Karya (persero) memiliki nilai debt to asset ratio yang kurang sehat disebabkan masih diatas nilai rata-rata industri. Untuk nilai debt to equity ratio mendapatkan hasil yang baik dalam kondisi sehat pada tahun 2013 disebabkan masih dibwah nilai rata-rata industri namun, dari tahun 2014-2017 hasilnya kurang sehat disebabkan masih diatas nilai rata-rata industri. Lalu nilai long term debt to equity ratio hasilnya kurang sehat dari tahun 2013-2014 dan tahun 2017 disebabkan masih diatas nilai rata-rata industri namun, dari tahun 2015-2016 mendapatkan hasil yang baik dalam kondisi sehat disebabkan masih dibwah nilai rata-rata industri. Kemudian untuk nilai times interest earned ratio hasilnya kurang sehat daari tahun 2013-2016 disebabkan masih diatas nilai rata-rata industri namun, pada tahun 2017 mendapatkan hasil yang baik dalam kondisi sehat disebabkan masih dibawah nilai rata-rata industri dan nilai operating income to liabilities ratio mendapatkan hasil yang baik dalam kondisi sehat disebabkan masih dibawah nilai rata-rata industri. PT. Surya Semesta Internusa Tbk memiliki nilai debt to asset ratio yang baik dalam kondisi sehat disebabkan masih dibawah nilai rata-rata industri. Untuk debt to equity ratio hasilnya kurang sehat pada tahun 2013 disebabkan masih diatas nilai rata-rata industri namun, dari tahun 2014-2017 mendapatkan hasil yang baik dalam kondisi sehat disebabkan masih dibawah nilai rata-rata industri. Lalu nilai long term debt to equity ratio mendapatkan hasil yang baik dalam kondisi sehat dari tahun 2013-2015 dan tahun 2017 disebabkan masih dibawah nilai rata-rata industri namun, pada tahun 2016 hasilnya kurang sehat disebabkan masih diatas nila rata-rata industri. Kemudian untuk nilai times interest earned ratio hasilnya kurang sehat dari tahun 2013-2015 dan tahun 2017 disebabkan masih diatas nilai rata-rata industri namun, pada tahun 2016 mendapatkan hasil yang baik dalam kondisi sehat disebabkan masih dibawah nilai rata-rata industri dan untuk nilai operating income to liabilities ratio hasilnya kurang sehat disebabkan masih diatas nilai rata-rata industri. Oleh karena itu 
perusahaan PT. Surya Semesta Internusa Tbk lebih unggul dan lebih sehat dalam kemampuannya memenuhi utang atau kewajiban jangka panjang dan kewajiban lainnya dibandingkan dengan perusahaan PT. Adhi Karya (persero) Tbk.

\section{DAFTAR PUSTAKA}

Hery, H. (2012). Rahasia Cermat dan Mahir Menganalisis Laporan Keuanagan. Jakarta: PT Grasindo

Hery, H. (2015). Analisis Laporan Keuangan Pendekatan Rasio Keuangan. Yogyakarta: PT. Buku Seru

Munawir, M. (2013) Analisis Laporan Keuangan. Yogyakarta

Sunyoto, D. (2013). Analisis Laporan Keuangan untuk Bisnis. Yogyakarta: Caps Publishing

Wahyudiono, B. (2014). Mudah Membaca Laporan Keuangan. Jakarta: Raih Asa Sukses (Penebar Swadaya Grup)

www.idx.co.id 